\title{
EKSISTENSI PENDIDIKAN AGAMA ISLAM DALAM MEMBANGUN TOLERANSI BERAGAMA
}

\author{
Maemunah \\ (maemunah.88@gmail.com) \\ Dosen Sekolah Tinggi Ilmu Tarbiyah (STIT) Islamic Village Tangerang
}

\begin{abstract}
Abstrak: Pendidikan agama di sebuah sekolah merupakan sebuah mata pelajaran yang wajib diselenggarakan karena peranan dan kontribusi pendidikan agama sangat penting dalam pengembangan sikap toleransi keagamaan, sehingga tercipta budaya sekolah yang baik. Pendidikan agama Islam dan pendidikan agama lainnya tentu menekankan pada pengajaran mengenai norma, moral, dan etika yang baik yang bertujuan mengembangkan potensi peserta didik agar menjadi pribadi yang baik. Pendidikan Agama Islam juga tak kalah penting dengan segala jenis pendidikan lainnya. Hal tersebut dikarenakan pendidikan Islam merupakan suatu lembaga pendidikan yang mengajarkan tentang kedamaian dan kerukunan dalam masyarakat dan menjungjung tinggi nilai-nilai kemanusiaan. Dan agama mampu meredam segala persoalaan kehidupan atau konflik yang terjadi di tengahtengah masyarakat akibat berbagai perbedaan, sehingga dapat membangun toleransi beragama.
\end{abstract}

Kata Kunci: Toleransi Beragama, Pendidikan Agama Islam, Tasamuh.

\section{A. Pendahuluan}

Keberhasilan dan kemajuan sebuah negara tidak lepas dari sistem kualitas pendidikan negaranya yang baik. Pendidikan yang baik tentu akan membentuk suatu pribadi dan komunitas masyarakat yang berbudaya dan bermartabat tinggi. Dengan masyarakat yang berbudaya dan bermartabat tinggi, tentu akan menciptakan manusia yang menjungjung tinggi nilai kemanusiaan dan menciptakan kerukunan dan kedamaian serta bertoleransi tinggi dalam keberagaman. Pendidikan agama di lembaga pendidikan maupun lembaga pendidikan pada ormas keagamaan, tentunya harus merespon pluralitas dalam mekanisme pendidikannya, sehingga ada upaya untuk merekonstruksi dan mendesain model, tujuan, proses, program, serta proses evaluasi yang akan digunakan. Pendidikan yang dikembangkan harus memiliki wawasan terhadap keagamaan, baik kelompok, keyakinan, etnis, maupun aspek lainnya. ${ }^{52}$

${ }^{52}$ Baidhawy, Religion education Multicultural Perspective, (Surakarta: Pusat Studi Budaya dan Perubahan Sosial Universitas Muhammadiyah Surakarta, 2005), h. 86-90 
ISTIGHNA, Vol. 1, No 1, Januari 2018 P-ISSN 1979-2824

Homepage: http://e-journal.stit-islamic-village.ac.id/index.php/istighna

Maemunah

Eksistensi Pendidikan Agama Islam Dalam Membangun Toleransi Beragama

Indonesia, sebagai negara yang bertaburan etnik, agama, bahasa, kelompok sosial, dan nilai, memiliki tantangan tersendiri. Tantangan yang paling utama adalah bagaimana meramu segala entitas perbedaan itu menjadi suatu tatanan masyarakat yang demokratis. Tentu tantangan itu, bukan hanya menjadi tangggung jawab negara saja, tetapi itu tugas seluruh bangsa ini dalam menata kehidupan bersama dalam meramu segala perbedaan. ${ }^{53}$

Perbedaan dapat memicu terkaitnya adanya konflik sosial bernuansa agama yang terjadi di berbagai daerah, disebabkan oleh antara lain bahwa agama dalam kehidupan masyarakat merupakan hal yang sensitif, sehingga melalui sentimen keagamaan seseorang atau kelompok orang secara psikologis mudah dimobilisasi dan dimanfaatkan oleh kelompok yang sedang konflik untuk memperoleh dukungan. Kasus-kasus konflik sosial bernuansa agama yang pernah terjadi di berbagai daerah selama ini, seperti di Tasikmalaya (1996), Ketapang (1999), Poso (1999), Sambas (1999), Temanggung (2010) dan Ambon (1999, 2011), menunjukkan betapa faktor agama 2 Toleransi Beragama di Daerah Rawan Konflik diikutsertakan dalam nuansa konflik. Penyebab utamanya adalah faktor non keagamaan, seperti: politik, ekonomi dan budaya. Kasus konflik di Ambon Maluku pada pasca runtuhnya rezim Orde Baru di atas, selain akibat dari adanya kondisi distorsi komunikasi dan informasi sistemik, juga akibat dari rentannya masyarakat terhadap aksi provokatif dan politisasi isu agama, etnis dan separatis, hal ini diperkuat oleh beberapa hasil studi dan pemetaan konflik Maluku yang menyebutkan bahwa gerakan bakubae Maluku menetapkan sumber konflik berakar pada konflik elit politik sipil-militer dengan mengeksploitasi dan memolitisasi emosi agama. ${ }^{54}$

Dalam hal ini, tentu pendidikan agama harus bisa membantu menumbuhkan rasa toleransi dalam segala aspek kehidupan. Tidak dapat dipungkiri bahwa dewasa ini terdapat berbagai permasalahan sosial yang disebabkan oleh kurangnya toleransi dalam kehidupan beragama. Kita pasti tidak lupa dengan masalah yang terjadi di Ambon dan Poso dulu yang sampai memakan korban karena kurangnya

\footnotetext{
${ }^{53}$ Felix Baghi, Pluralisme, Demokrasi, dan Toleransi, (Maumere: Ladero, cet.1, 2012), h. 8

${ }^{54}$ Kementrian Agama RI Badan Litbang dan Diklt Puslitbang, Toleransi Beragama di Daerah Rawan Konflik, (Jakarta: Puslitbang Kehidupan Keagamaan, cet.1, 2016), h. 2
} 
ISTIGHNA, Vol. 1, No 1, Januari 2018 P-ISSN 1979-2824

Homepage: http://e-journal.stit-islamic-village.ac.id/index.php/istighna

Maemunah

Eksistensi Pendidikan Agama Islam Dalam Membangun Toleransi Beragama

toleransi antar umat beragama. Oleh karena itu, untuk mengantisipasi agar hal itu tidak terjadi lagi maka diperlukan suatu formula atau model dalam dunia pendidikan terutama pendidikan agama sehingga toleransi antar umat beragama dapat terwujud.

\section{B. Pengertian Toleransi}

Istilah tolerance (toleransi) adalah istilah modern, baik dari segi nama maupun kandungannya. Istilah ini pertama kali lahir di Barat, di bawah situasi dan kondisi politis, sosial, dan kebudayaannya yang khas. Toleransi berasal dari bahasa Latin, yaitu "tolerantia", yang artinya kelonggaran, kelembutan hati, keringanan dan kesabaran. Menurut Bertelsmann Stiftung, toleransi adalah nilai inti dari masyarakat majemuk yang memungkinkan untuk membangun interaksi dan integrasi antara berbagai macam budaya dan pendapat. ${ }^{55}$ Pendapat ini, menyatakan bahwa toleransi akan timbul di tengah-tengah kehidupan masyarakat dengana adanya keragaman budaya dan gagasan-gagasan dai pemikiran manusia. Dalam percakapan sehari-hari, disamping kata toleransi, juga dipakai kata tolere. Kata tolere berasal dari Belanda, yang berarti memperbolehkan atau membiarkan, dengan pengertian membolehkan atau membiarkan yang pada prinsipnya tidak perlu terajadi. Jadi toleransi dalam kontek ini mengandung arti pemberian yang hanya didasarkan kepada kemurahan dan kebaikan hati, dan bukan didasarkan kepada hak. ${ }^{56}$

Menurut Kamus Besar Bahasa Indonesia, toleransi berasal dari kata toleran yang berarti "bersifat' atau "bersifat menenggang" (menghargai, membiarkan, memperbolehkan), pendirian (pendapat, pandangan, kepercayaan, kebiasaan, kelakuan dan sebagainya) yang berbeda atau bertentangan dengan pendirian sendiri. Toleransi dalam kontek sosial, budaya dan agama yang berarti sikap dan perbuatan yang melarang adanya diskriminasi terhadap kelompokkelompok yang berbeda atau tidak dapat diterima oleh mayoritas dalam suatu

\footnotetext{
${ }^{55}$ Bertelsmann Stiftung, "A Modern Concept of Tolerance Basis for Democratic Interaction in Pluralistic Societies,” http://www.bertelsmannstiftung.pdf (diakses pada tanggal 17 Juli 2017).

${ }^{56}$ Said Agil Husin Al-Munawwar, Fikih Hubungan Antar Agama, (Jakarta: Ciputat Press, 2005), h. 13
} 
ISTIGHNA, Vol. 1, No 1, Januari 2018 P-ISSN 1979-2824

Homepage: http://e-journal.stit-islamic-village.ac.id/index.php/istighna

Maemunah

Eksistensi Pendidikan Agama Islam Dalam Membangun Toleransi Beragama

masyarakat. Contohnya toleransi umat beragama, dimana penganut mayoritas dalam suatu masyarakat mengizinkan keberadaan agama-agama lainnya. ${ }^{57}$

Toleransi merupakan rasa hormat, penerimaan dan penghargaan terhadap keragamaan budaya yang ada di dunia. Hal tersebut berdasarkan pengetahuan, keterbuakaan, komunikasi, kebebasan berpikir, dan keyakinan. Toleransi juga bisa diartiakan kerukunan dalam perbedaan, sikap tanggung jawab yang menjungjung tinggi hak asasi manusia, pluralism, demokrasi dan suprimasi hukum, karena toleransi dapat membuat perdamaian di dunia ini. United Nations Educational, Scientific, and Cultural Organization (UNESCO) memandang bahwa toleransi sebagai sikap "saling menghormati, saling menerima, dan saling menghargai di tengah keragaman budaya, kebebasan berekspresi, dan karakter manusia". ${ }^{58}$ Dalam hal ini, toleransi erat hubungannya dengan sikap positif terhadap perbedaan dengan orang lain dengan menjungjung tinggi hak asasi setiap individu. Toleransi juga merupakan sikap untuk memberikan hak sepenuhnya kepada kepada orang lain agar menyampaikan pendapatnya, sekalipun pendapatnya salah dan berbeda dari yang lainnya.

\section{Toleransi dalam Perspektif Islam}

Toleransi dalam perspektif Islam, menyatakan bahwa perbedaan agama dan kepercayaan tidak dapat menghalangi manusia untuk saling bertoleransi dan menghargai manusia yang lain, karena Islam diturunkan bukan untuk suatu komunitas atau golongan tertentu, tetapi untuk seluruh umat manusia di dunia dengan prinsip rahmatan li al-'alamin. Dalam bahasa Arab, sulit mencari secara tepat arti yang menunjukkan toleransi yang sepadan dengan bahasa Inggris, akan tetapi umat Islam mulai mendiskusikan hal tersebut dengan istilah tasamuh. ${ }^{59}$ Dalam bahasa Arab tasamuh adalah derivasi ${ }^{60}$ dari "samh" yang berarti "juud wa

\footnotetext{
${ }^{57}$ Zagorin, Peres, How the Idea of Religious Toleration Came to the West, (Princeton University Press: 2003), h. 36

${ }^{58}$ UNESCO, "Learning to Live Together In Peaceand Harmony: Values Education for Peace, Human Rights, Democracy and Sustainable Development for the Asia-Pasific Region," http://unesdoc.unesco.org/pdf (diakses pada 17 Mei 2017)

${ }^{59}$ Tasamuh adalah tasahul (kemudahan) atau ukuran perbedaan yang dapat ditolerir. Lihat kamus al-Muhit, Oxford Study Dictionary English - Arabic, (Beirut: Academia, 2008), h. 1120

${ }^{60}$ Derivasi adalah proses pembentukan kata leksem baru (menghasilkan kata-kata yang berbeda dari paradigma yang berbeda), pembentukan derivasi bersifat tidak dapat diramalkan.
} 
ISTIGHNA, Vol. 1, No 1, Januari 2018 P-ISSN 1979-2824

Homepage: http://e-journal.stit-islamic-village.ac.id/index.php/istighna

Maemunah

Eksistensi Pendidikan Agama Islam Dalam Membangun Toleransi Beragama

karam wa tasahul" dan bukan "to endure without protest" (menahan perasaan tanpa protes) yang merupakan arti asli dari kata "tolerance". 61

Toleransi atau dalam bahasa Arab dikenal dengan tasamuh yang merupakan salah satu inti ajaran Islam. Sebagai yang fundamental dalam Islam, al-Qur'an mengajurkan umat Islam untuk bertoleransi terhadap sesama. Hal ini ditegaskan dengan penghormatan Islam terhadap Nabi Isa As dan Nabi Musa As yang begitu besar serta pengakuan keberadaan Taurat, Zabur, dan Injil dalam al-Qur'an. ${ }^{62} \mathrm{Hal}$ tersebut juga senada dengan pendapat Sayyid Qutub yang menyatakan, bahwa Islam adalah agama kasih sayang, aqidah yang lemah lembut, dan mempunyai cita-cita untuk mengumpulkan umat manusia dibawah kekuasaan Allah SWT dengan penuh cinta dan kasih sayang, Islam juga bukan agama yang identik dengan kekerasan dan permusuhan. ${ }^{63}$

Berbicara mengenai tasamuh, tentu tidak cukup dengan pengertian secara bahasa dan istilah saja. Untuk itu, perlu digali juga nilai-nilai yang terkandung dalam konsep tasamuh dalam Islam, karena setiap konsep tidak terlepas dari konsep dasar lainnya. Untuk itu, berikut adalah beberapa konsep nilai yang terkandung dalam tasamuh, ${ }^{64}$ diantaranya:

1. Al-Rahmah, ${ }^{65}$ merupakan salah satu konsep paling erat dengan konsep tasamuh dan merupakan salah satu sifat Allah SWT. Konsep al-Rahmah bertentangan dengan kekerasan dan sering disandingkan dengan kata alRahim (sayang) karena memiliki sumber yang sama yaitu rahima. Selain itu, al-Rahmah juga sering diucapkan dalam do'a para nabi terdahulu. Misalnya, Nabi Adam AS, Nabi Nuh AS, Nabi Musa AS, dan lain sebagainya.

2. Al-Salam, konsep lainnya yang terkait dengan konsep tasamuh adalah alSalam (keselamatan). Konsep ini berlaku untuk semua makhluk, kepada

${ }^{61}$ Lihat The New International Webster Chomprehensive Dictionary of The English Language, (Chicago: Trieden Press International, 2006), h. 1320

${ }^{62}$ Muhammad al-Ghazali, al-Islam al-Muftara 'Alayhi, (Kairo: Nahdatu Misr, 2008), h. 30

${ }^{63}$ Sayyid Qutub, Tafsir Fi Zilal al-Qur'an, jilid 4, (Kairo: Dar al-Syuruq, 1982), h. 3544

${ }^{64}$ Umar bin Abd Al-Aziz Al-Arin Quraisy, Samahah Al-Islam, h. 36

${ }^{65}$ Kata al-Rahmah adalah bentuk derivasi dari kata "rahima" yang berarti pengasih. 
ISTIGHNA, Vol. 1, No 1, Januari 2018 P-ISSN 1979-2824

Homepage: http://e-journal.stit-islamic-village.ac.id/index.php/istighna

Maemunah

Eksistensi Pendidikan Agama Islam Dalam Membangun Toleransi Beragama

kafir (dalam hal muamalah/peperangan), Islam lebih mengutamakan keselamatannya dari pada memeranginya.

3. Al- 'Adl, konsep ini tercermin dalam QS. al-Nahl ayat 90; "Sesungguhnya Allah menyuruh (kamu) berlaku adil dan berbuat kebajikan, memberi kepada kaum kerabat, dan Allah melarang dari perbuatan keji, kemungkaran dan permusuhan, dia memberi pengajaran kepadamu agar kamu dapat mengambil pelajaran”. Dalam ayat ini, Allah SWT memerintahkan ummat-Nya untuk berbuat tiga hal yaitu, adil, ihsan/ kebaikan, dan menjalin silaturrahim.

4. Al-Tauhid, merupakan konsep yang paling tinggi yang berhubungan dengna konsep tasamuh, karena konsep inilah yang membedakan makna toleransi antara Islam dengan yang lainnya. Menurut Ismail Raji al-Faruqi, tauhid merupakan pengakuan bahwa Allah SWT adalah sumber Tuhan semesta alam. Hal ini berarti bahwa Allah SWT adalah sumber hakiki semua kebaikan, semua nilai, apa yang diketahui dengan indera adalah benar sifatnya, kecuali jika indera kita jelas cacat atau sakit, apa yang tampak sesuai dengan akal sehat adalah benar. Tauhid menggariskan optimisme dalam bidang epistimologi dan etika, inilah yang disebut dengan toleransi sebenarnya. ${ }^{66}$

Agama Islam memandang bahwa toleransi berlaku untuk setiap individu, baik dengan sesama umat muslim maupun dengan umat non-muslim. Empat faktor unik yang menyebabkan perilaku yang mendominasi umat muslim bertoleransi terhadap non-muslim, antara lain sebagai berikut:

1. Keyakinan terhadap kemuliaan manusia, apapun agamanya, kebangsaannya dan kerukunannya. Hal tersebut seseuia dengan QS. AlIsra ayat 70, "Dan sungguh, kami telah memulaikan anak cucu Adam, dan Kami angkut mereka di darat dan di laut, dan Kami beri mereka rezeki dari yang baik-baik dan Kami lebihkan mereka di atas banyak makhluk yang Kami ciptakan dengan kelebihan yang sempurna".

\footnotetext{
${ }^{66}$ Ismail Raji Al-Faruqi, Tauhid, (Bandung: Pustaka, 2008), h. 47
} 
ISTIGHNA, Vol. 1, No 1, Januari 2018 P-ISSN 1979-2824

Homepage: http://e-journal.stit-islamic-village.ac.id/index.php/istighna

Maemunah

Eksistensi Pendidikan Agama Islam Dalam Membangun Toleransi Beragama

2. Perbedaan bahwa manusia dalam agama dan keyakinan merupakan realitas yang dikehendaki Allah SWT karena telah itu memberikan kebebasan untuk memilih iman dan kufur. Hal tersebut dapat di lihat dalam QS. AlKahfi ayat 29, "Dan katakanlah: "Kebenaran itu datangnya dari Tuhanmu, maka barang siapa yang ingin (beriman) hendaklah ia beriman, dan barang siapa yang ingin (kafir) biarlah ia kafir”. Sesuangguhnya kami telah sediakan bagi orang-orang zalim itu neraka, yang gejolaknya mengepung mereka. Dan jika mereka meminta minum, niscaya mereka akan diberi minuman dengan air seperti besi yang mendidih yang menghanguskan muka. Itulah minuman yang paling buruk dan tempat istirahat yang paling jelek".

3. Seorang muslim tidak dituntut untuk mengadili kekafiran seseorang atau menghakimi sesatnya orang lain, karena hanya Allah SWT yang akan menghakiminya kelak. Seperti dalam QS. Al-Hajj ayat 68-69, "Dan jika mereke membantah engkau, maka katakanlah: Allah akan mengadili diantara kamu pada hari kiamat tentang apa yang dahulu kamu memperselisihkannya".

4. Keyakinan bahwa Allah SWT memerintahkan untuk berbuat adil dan mengajak kepada budi pekerti mulia, meskipun kepada orang musyrik. Allah SWT juga mencela perbuatan dzalim meskipun kepada kafir. Hal tersebut sesuai dengan QS. Al-Maidah ayat 8, “Wahai orang-orang yang beriman! Jadilah kamu penegak keadilan karena Allah (ketika) menjadi saksi yang adil. Dan janganlah kebencianmu terhadap suatu kaum mendorong kamu untuk berlaku tidak adil. Berlaku adillah. Karena (Adil) itu lebih dekat kepada takwa. Dan bertakwalah kepada Allah, sungguh, Allah maha mengetahi terhadap apa yang kamu kerjakan”. ${ }^{67}$

Islam mengakui dan menjungjung tinggi al-ukhuwwah al Basyariah disamping al-ukhuwwah al-Islamiyah. Islam pun menyerukan pergaulan atau interaksi sosial universal ini dengan asas persamaan dan persaudaraan, untuk

${ }^{67}$ Yusuf al-Qardhawi, Ghairul-Muslimin fiiil Mujtama” Al Islami, (Qahirah: Maktabah AlWahbah, 2002), h. 53-55 
ISTIGHNA, Vol. 1, No 1, Januari 2018 P-ISSN 1979-2824

Homepage: http://e-journal.stit-islamic-village.ac.id/index.php/istighna

Maemunah

Eksistensi Pendidikan Agama Islam Dalam Membangun Toleransi Beragama

saling kenal secara harmonis antar sesama, tanpa melihat latar belakang agamanya.

\section{Eksistensi Pendidikan Islam di Indonesia}

Pendidikan agama Islam saat ini mengalami proses perkembangan yang sangat maju, dan hal tersebut tidak terlepas dari sejarah perjuangan kemerdekaan bangsa ini. Keberadaan pendidikan agama Islam juga ada hubungan erat dengan keterkaitannya dengan sistem dan isi pendidikan agama Islam. Sistem pendidikan agama Islam, pada awalnya dilaksanakan secara informal, dan sistem informal ini berlangsung secara terus menerus di lingkungan masyarakat dan berhubungan langsung dengan dengan pola penyebaran Islam di Indonesia. Proses pendidikan agama Islam pun dilakukan di lembaga seperti surau, langgar, atau masjid-masjid. Hal tersebut dilakukan terus menerus sampai sistem pendidikan agama Islam berkembang menjadi sistem pendidikan formal, serperti melalui institusi formal pondok pesantren dan madrasah atau sekolah yang berdasarkan keagamaan. ${ }^{68}$

Sedangkan isi pendidikan agama Islam di Indonesia, tidak dapat dipisahkan dari tujuan pendidikan agama Islam. Tujuan pendidikan agama Islam itu sebagaimana yang tercantum dari hasil konferensi Dunia pertama tentang Pendidikan Agama Islam pada tahun 1977, menegaskan bahwa tujuan akhir pendidikan Islam adalah terbentuknya manusia yang menyerahkan diri secara mutlak kepada Allah SWT. ${ }^{6}$ Peraturan Pemerintah Nomor 55 tahun 2007, memberikan tempat bagi pelaksanaan pendidikan agama, baik di sekolah umum, madrasah dan pendidikan keagamaan yang diselenggarakan oleh masyarakat. Hal tersebut juga merajuk kepada Undang-Undang Nomor 20 Tahun 2003, pendidikan agama dan keagamaan yang dilaksanakan melalui pendidikan formal, non formal, dan informal berada di bawah tanggung jawab pemerintah seutuhnya. Sistem Pendidikan Nasional juga mengaskan bahwa anak di sekolah berhak mendapatkan pendidikan menurut agama yang diyakininya. Dan diajarkan oleh guru yang seagama. Dulu peraturan perundangan mensyaratkan adanya minimal 10 murid

${ }^{68}$ Moh. Kasiram, dkk,. Sejarah Pendidikan Islam, cet II, (Jakarta: Dirjen Pembinaan Kelembagaan Agama Islam, 1986)

${ }^{69}$ Ahmad Tafsir, Ilmu Pendidikan dalam Perspektif Islam, Cet.IX, (Bandung: Remaja Rosdakarya, 2010), h. 48 
ISTIGHNA, Vol. 1, No 1, Januari 2018 P-ISSN 1979-2824

Homepage: http://e-journal.stit-islamic-village.ac.id/index.php/istighna

Maemunah

Eksistensi Pendidikan Agama Islam Dalam Membangun Toleransi Beragama

agama yang berbeda, untuk penyelenggaraan pendidikan agama di sebuah sekolah. Peraturan perundangan sekarang telah memungkinkan satu anakpun yang berbeda agama dengan agama yang mayoritas di sekolah, maka berhak mendapatkan pendidikan agama yang dianut anak tersebut. ${ }^{70}$

Dalam kurikulum, mata pelajaran yang terkait dengan peningkatan dan pengembangan akidah peserta didik adalah kurikulum Pendidikan Agama Islam (PAI). Kurikulum PAI diarahkan untuk mewujudkan muslim yang baik, sehingga desain kurikulumnya terdiri atas empat dasar pokok, yaitu dasar agama, dasar falsafah, dasar psikologis, dan dasar sosial. ${ }^{71}$

\section{E. Pendidikan Agama Islam dalam Memebangun Toleransi Beragama}

Pendidikan toleransi beragama pada hakikatnya adalah proses pendidikan yang menanamkan nilai-nilai agar peserta didik mampu hidup berdampingan secara harmonis dalam realitas keagaamaan dan berprilaku positif sehingga dapat mengelola keberagaman menjadi kekuatan tanpa menghapuskan identitas diri dan budayanya. $^{72}$ Model pendidikan yang dibutuhkan di Indonesia harus memperhatikan enam hal yaitu;

1. Pendidikan multikultural haruslah bedimensi "right to culture" dan identitas lokal.

2. Kebudayaan Indonesia yang merupakan konsep yang terus berproses dan merupakan bagian integral dari proses kebudayaan mikro, perlu untuk mengoptimalkan budaya lokal yang beriringan dengan apresiasi terhadap budaya nasional.

3. Pendidikan multikultural normatif, yaitu model pendidikan ang memperkuat identitas budaya lokal yang ada.

${ }^{70}$ Kantor Wilayah Kementrian Agama Sosialisasikan PP No.55 Tahun 2007 Tentang Pendidikan Agama dan Keagamaan, Direktorat Jendral Pendidikan Islam Kementrian Agma RI, http://pendis.kemenag.go.id (Diakses 12 Mei 2017).

${ }^{71}$ Omar Muhammad al-Toumy Al-Syaibani, Falsafah Pendidikan Islam, penerjemah Hasan Langgulung (Jakarta: Bulan Bintang, 1979), h. 524

${ }_{72}$ Direktorat Pendidikan Agama Islam pada Sekolah Departemen Agama RI, Laporan Workshop Penelitian Multikultural Pertama, (Jakarat: Direktorat Pendidikan Agama Islam pada Sekolah Departemen Agama RI, 2008), h. 6 
ISTIGHNA, Vol. 1, No 1, Januari 2018 P-ISSN 1979-2824

Homepage: http://e-journal.stit-islamic-village.ac.id/index.php/istighna

Maemunah

Eksistensi Pendidikan Agama Islam Dalam Membangun Toleransi Beragama

4. Pendidikan multikultural merupakan suatu rekonstruksi sosial, artinya pendidikan multikultural tidak boleh terjebak pada fanatisme dan fundamentalisme, baik etnik, suku, maupun agama.

5. Pendidikan multikultural merupakan pendidikan pedagogik pemberdayaan (pedagogy of empowerment) dan pedagogik kesetaraan dalam kebudayaan yang beragam (pedagogy of equity). Keenam, pendidikan multikultural bertujuan mewujudkan visi Indonesia masa depan serta etika bangsa. Pendidikan ini perlu dilakukan untuk mengembangkan prinsip-prinsip etis (moral) masyarakat Indonesia yang dipahami oleh keseluruhan komponen sosial budaya yang plural. ${ }^{73}$

Dengan model pendidikan yang seperti disebutkan diatas tadi, diharapkan mampu membentuk karakter dan mental masyarakat Indonesia menjadi lebih mengerti dan memahami lagi betapa pentingnya toleransi itu dalam kehidupan karena manusia itu adalah makhluk sosial yang pasti membutuhkan orang lain. Pendidikan merupakan sebuah pembelajaran pengetahuan, keterampilan, dan kebiasaan sekelompok orang yang diturunkan dari satu generasi ke generasi berikutnya melalui pengajaran, pelatihan, atau penelitian. Pendidikan biasanya terjadi melalui bimbingan orang lain, tetapi juga memungkinkan terjadi secara otodidak. ${ }^{74}$ Di Amerika, pendidikan toleransi beragama di sekolah umum telah telah ada semenjak awal mulanya didirikan sekolah-sekolah yang ada di Amerika. Pada awal tahun 1600 M, warga negara yang mayoritas beragama Protestan, mendirikan sekolah di New England Colonies, yang kurikulumnya berdasarkan keimanan Protestan dan berfungsi sebagai pondasi filosifis sistem sekolah umum. $^{75}$

Pendidikan agama Islam juga tak kalah penting dengan segala jenis pendidikan lainnya. Hal tersebut dikarenakan pendidikan Islam merupakan suatu lembaga pendidikan yang mengajarkan tentang kedamaian dan kerukunan dalam

${ }^{73}$ H.A.R. Tilaar, Multikulturalisme: Tantangan-Tantangan Global Masa Depan dalam Transformasi Pendidikan Nasional, (Jakarata: Grasindo, 2004), h. 185

${ }_{75}$ John Dewey, Democracy and Education, (The Free Press), h. 1-4

75 Jenice R. Russel and James T. Richardson, Religious Tolerance, Education and The Curriculum, The Netherlands (2011), 12. http://www.sensepublishers.com (diakses tanggal 15 April 2017) 
ISTIGHNA, Vol. 1, No 1, Januari 2018 P-ISSN 1979-2824

Homepage: http://e-journal.stit-islamic-village.ac.id/index.php/istighna

Maemunah

Eksistensi Pendidikan Agama Islam Dalam Membangun Toleransi Beragama

masyarakat dan menjungjung tinggi nilai-nilai kemanusiaan. Dan agama mampu meredam segala persoalaan kehidupan atau konflik yang terjadi ditengah-tengah masyarakat akibat berbagai perbedaan. Oleh karena itu, justifikasi agama dalam suatu konflik, khususnya konflik yang timbul pada antar penganut agama-agama yang berbeda sangat mudah muncul ke permukaan. Kondisi semacam itu, menjadikan agama sebagai elemen penting sebagai pemersatu masa (kelompok) yang histeris dan anarkis. Demikian pula simbol-simbol agama menjadi teriakanteriakan pembangkit semangat yang efektif. ${ }^{76}$ Bahwa agama tidak hanya menjadi penyebab konflik tapi juga menjadi pemicu perdamaian, maka toleransi beragama di daerah rawan konflik sangat menarik dan memiliki posisi strategis sebagai bahan untuk meningkatkan hubungan yang harmonis di kalangan umat beragama di daerah yang bersangkutan. Selain itu, toleransi beragama ini diperlukan sebagai upaya pengungkapan sisi lain yang positif bagi peningkatan kerukunan yang secara realita terdapat dan berlangsung dalam kehidupan umat beragama. ${ }^{77}$

Dalam dunia akademik, gagasan tentang pentingnya penanaman dan apresiasi terhadap dimensi toleransi muncul sebagai respon adanya perbedaan dalam diskriminatif, seperti halnya perbedaan ras, kelas social dalam hal ekonomi, gender, bahasa, serta peserta didik yang memiliki kebutuhan khusus, setelah Perang Dunia II. Hal tersebut terjadi karena kaum imigran di berbagai negara yang umumnya minoritas mendapatkan perlakuan diskriminatif, sehingga membutuhkan pengakuan. ${ }^{78}$ Hal tersebut juga dikemukakan oleh H.A.R Tilaar yang menyatakan bahwa masyarakat multikultural sebenarnya menyimpan banyak kekuatan dari masing-masing kelompok, namun di satu sisi juga menyimpan benih perpecahan apabila tidak dikelola dengan baik dan rasional. ${ }^{79}$

Dalam pelaksanaannya di dunia pendidikan, James A. Banks menjelaskan lima dimensi yang harus ada yaitu; pertama, adanya integrasi pendidikan dalam

76 Azyumardi Azra, Menuju Masyarakat Madani, Gagasan, Fakta, dan Tantangan, (Bandung: PT. Remaja Rosda Karya, 1990), h. 11

${ }^{77}$ Kementrian Agama RI Badan Litbang dan Diklat Puslitbang, Toleransi Beragama di Daerah Rawan Konflik, (Jakarta: Puslitbang Kehidupan Keagamaan, Cet.1, 2016), h. 5

${ }^{78}$ Gurbachan Singh, Equality and Education, (Derby: Albrighto Publications, 1993), h. 7

${ }^{79}$ H.A.R. Tilaar, Multikulturalisme: Tantangan-Tantangan Global Masa Depan dalam Transformasi Pendidikan Nasional, h. 37 
ISTIGHNA, Vol. 1, No 1, Januari 2018 P-ISSN 1979-2824

Homepage: http://e-journal.stit-islamic-village.ac.id/index.php/istighna

Maemunah

Eksistensi Pendidikan Agama Islam Dalam Membangun Toleransi Beragama

kurikulum (content Integration) yang di dalamnya melibatkan keragaman dalam satu kultur pendidikan, mengintegrasikan berbagai budaya dan kelompok untuk mengilustrasikan konsep dasar, generalisasi, dan teori dalam mata pelajaran/disiplin ilmu yang tujuan utamanya adalah menghapus prasangka. Kedua, konstruksi ilmu pengetahuan (knowledge construction) yang diwujudkan dengan mengetahui dan memahami secara komperhensif keragaman yang ada dan membawa siswa untuk memahami implikasi budaya ke dalam sebuah mata pelajaran. Ketiga, pengurangan prasangka (prejudice reduction) yang lahir dari interaksi antar keragaman dalam kultrul pendidikan, mengindentifikasi karakteristik ras siswa dan menentukan metode pengajaran mereka. Kemudian, melatih kelompok untuk ikut berpartisipasi dalam kegiatan olahraga, berinteraksi dengan seluruh staf dan siswa yang berbeda etnis dan ras dalam upaya menciptakan budaya akademik yang toleran dan inklusif. Keempat, pedagogik kesetaraan manusia (equity pedagogy) yang memberi ruang dan kesempatan yang sama kepada setiap elemen yang beragam, menyesuaikan metode pengajaran dengan cara belajar siswa dalam rangka memfasilitasi prestasi akademik siswa yang beragam baik dari segi ras, budaya, ataupun sosial. Dan yang terakhir, kelima, pemberdayaan kebudayaan sekolah (empowering school cultures). ${ }^{80}$

Untuk itu, pendidikan agama di sebuah sekolah merupakan sebuah mata pelajaran yang wajib diselenggarakan. Karena peranan dan kontribusi pendidikan agama sangat penting dalam pengembangan sikap toleransi keagamaan, sehingga tercipta budaya sekolah yang baik. Pendidikan agama Islam dan pendidikan agama lainnya tentu menekankan pada pengajaran mengenai norma, moral dan etika yang baik yang bertujuan mengembangkan potensi peserta didik agar menjadi pribadi yang baik. Pendidikan di sekolah juga berperan dalam menyelesaikan perpecahan yang terjadi di masyarakat. Selain itu, pendidikan harus mampu memberikan penyadaran kepada masyarakat bahwa konflik bukan suatu hal yang baik untuk dibudayakan. Sudah saatnya pendidikan memberikan jalan keluar yang mencerdaskan melalui desain metode dan materi pembelajaran,

80 James A. Bank, Handbook of Research on Muticultural Education http://www.educationworld.com (diakses pada tanggal 27 Maret 2017) 
ISTIGHNA, Vol. 1, No 1, Januari 2018 P-ISSN 1979-2824

Homepage: http://e-journal.stit-islamic-village.ac.id/index.php/istighna

Maemunah

Eksistensi Pendidikan Agama Islam Dalam Membangun Toleransi Beragama

serta kurikulum yang dapat menyadarkan masyarakat akan pentingnya memiliki sikap saling toleran sebagai aplikasi dari nilai-nilai dasar yang menanamkan sikap hormat terhadap perbedaan suku, agama, ras, etnis, da budaya bangsa Indonesia yang majemuk. Sebab nilai-nilai dasar dari pendidikan ini adalah penenman dari nilai toleransi, empati, simpati, dan solidaritas sosial. ${ }^{81}$

Oleh karena itu, yang perlu dibangun dalam di masa yang akan datang adalah upaya merumuskan visi toleransi Islam dengan mengacu pada paradigma yang tersimpan dalam Al-Qur'an untuk membangun kerukunan, dialog dan perdamaian. ${ }^{82}$ Hal tersebut diharapkan dapat membangun kerukunan dan perdamaian terutama di dalam dunia pendidikan yang ada di Indonesia. Di dunia pendidikan, tentu banyak sekolah yang mengajarkan toleransi untuk menciptakan kerukunan dan persatuan. Salah satu diantara model sekolah yang mengajarakan tentang toleransi yaitu Madina Progressive Indonesian School, sekolah yang terletak di wilayah Parung Bogor. Madina Progressive Indonesian School merupakan sebuah lembaga pendidikan yang sudah menerapkan pembelajaran agama Islam dengan menggunakan pendekatan humanistik kontektual sehingga niai-nilai toleransi dan keberagamaan yang terdapat di dalam ruang lingkup Pendidikan Agama Islam (PAI) dapat terintegrasi dengan baik dalam proses pembelajaran. ${ }^{83}$ Selain itu, sebagai upaya membentuk sikap toleransi beragama dapat dilakukan dengan cara sebagai berikut:

1. Melakukan kegiatan-kegiatan sosial yang melibatkan para pemeluk agama yang berbeda.

2. Mengubah orientasi pendidikan agama yang menekankan aspek fiqhiyah menjadi pendidikan agama yang berorientasi pada pengembangan aspek universal rabbaniyah.

81 A. Fuad Fanani, Islam Mazhab Kristis: Menggagas Keragaman Liberti, (Jakarta: Kompas Gramedia, 2004), h. 16

${ }^{82}$ Zuhairi Misrawi, Al-Qur'an Kitab Toleransi: Tafsir Tematik Islam Rahmatan Lil'alamin, (Jakarta: Grasindo, (Pustaka: Oasis), 2010), h. 353

83 Yayah Nurmaliah, Pendidikan Agama Islam Pluralis, (disertasi SPs UIN Syarif Hodayatullah Jakarta, 2009). 
ISTIGHNA, Vol. 1, No 1, Januari 2018 P-ISSN 1979-2824

Homepage: http://e-journal.stit-islamic-village.ac.id/index.php/istighna

Maemunah

Eksistensi Pendidikan Agama Islam Dalam Membangun Toleransi Beragama

3. Meningkatkan pembinaan individu yang mengarah pada terbentuknya pribadi yang memiliki budi pekerti yang luhur dan akhlaqul karimah. ${ }^{84}$

Menindak lanjuti terkait dengan pendidikan, peran besar dan kontribusi yang mendalam adalah terkait dengan pendidikan agama Islam. Pendidikan Agama Islam, menjadi sebuah sorotan dalam segala persoalan yang terjadi di dunia pendidikan dan mempunyai kontribusi yang penting dalam membangun bangsa terutama dalam hal toleransi beragama yang menciptkaan keharmonisan dan kedamaian berbangsa dan bernegara. Kemajemukan sudah merupakan sunnatullah, sebagaimana yang tercantum dalam QS. Al Hujurat [49]:13., yaitu: "Wahai manusia! Sungguh, kami telah menciptakan kamu dari seorang laki-laki dan seorang perempuan, kemudian kami jadikan kamu berbangsa-bangsa dan bersuku-suku agar kamu saling mengenal. Sungguh, yang paling mulia diantara kamu di sisi Allah ialah orang yang paling bertaqwa. Sungguh, Allah maha mengetahui, maha teliti."

Oleh karena itu, pendidikan dari dulu sampai sekarang masih diyakini mempunyai peran besar dalam membentuk karakter individu-individu yang dididiknya. Hal tersebut menjadi pertimbangan, bahwa salah satu peran dan fungsi pendidikan agama diantaranya adalah untuk meningkatkan keberagamaan peserta didik dengan keyakinan agamanya sendiri, dan memberikan kemungkinan keterbukaan untuk menumbuhkan sikap toleransi terhadap agama lain. Dalam hal ini, tentu pengajaran agama Islam yang diajarkan di sekolah-sekolah dituntut untuk selalu menanamkan nilai-nilai toleransi beragama. ${ }^{85}$ Kontribusi Pendidikan Agama Islam dalam menciptakan suasana toleran di sekolah, ada beberapa faktor yang berpengaruh diantaranaya adalah kurikulum, kompetensi guru dan lingkungan sekolah.

1. Kurikulum

Sebagai mata pelajaran yang terkait dengan peningkatan dan pengembangan akidah peserta didik, kurikulum Pendidikan Agama Islam (PAI) berlandaskan prinsip dan ajaran yang berkaitan erat dengan akidah,

\footnotetext{
${ }^{84}$ Dadang Kahmad, Sosiologi Agama, (Bandung: Rosda Karya, 2000), h. 151-152

85 Syamsul Ma'arif, Pendidikan Pluralisme di Indonesia, (Jogjakarta: Logung Pustaka,
} 2005), h. 7 
ISTIGHNA, Vol. 1, No 1, Januari 2018 P-ISSN 1979-2824

Homepage: http://e-journal.stit-islamic-village.ac.id/index.php/istighna

Maemunah

Eksistensi Pendidikan Agama Islam Dalam Membangun Toleransi Beragama

ibadah, mu'amalah (hubungan-hubungan yang berlaku di masyarakat). Ketiga unsur tersebut merupakan subtansi yang tidak dapat dipisahkan karena mencangkup aspek hubungan manusia dengan Allah, aspek hubungan manusia dengan manusia, dan aspek hubungan manusia dengan alam. $^{86}$

2. Kompetensi guru

Dalam kompetensi guru, ada empat standar yang harus dimiliki seorang guru untuk menjadi kreteria dan kemampuan mendasar dalam mencapai tujuan pendidikan, agar tidak keluar dari fiungsinya dan mampu berkontribusi dengan siswa, orang tua siswa, masyarakat, bangsa dan negara. Kompetensi tersebut adalah:

a. Kompetensi Pedagogik, kompetensi ini terkait dengan kemampuan atau kesungguhannya dalam mempersiapkan proses kegiatan belajar mengajar, kemampuan mengelola kelas, kedisiplinan dan kepatuhan terhadap aturan akadamik, penugasan media dan teknologi pembelajaran, kemampuan melaksanakan penilaian hasil peserta didik, objektivitas dalam penilaian dan berpersepsi positif terhadap kemampuan peserta didik. ${ }^{87}$ Selain itu, kompetensi pedagogik guru seorang guru harus sesuai dengan Peraturan Menteri Pendidikan Nasional RI Nomor 16 Tahun 2007 tentang Standar Kualifikasi Akademik dan Kompetensi Guru. ${ }^{88}$

b. Kompetensi Kepribadian, yang dimaksud dengan kompetensi ini adalah kemampuan kepribadian yang mantap, stabil, dewasa, arif dan berwibawa, menjadi teladan bagi peserta didik, dan berakhlak mulia. ${ }^{89}$

c. Kompetensi Sosial, dalam kompetensi ini yang harus dimiliki seorang guru, meliput; pertama, bersikap inklusif, bertindak objektif, serta tidak diskriminatif. Kedua, berkomunikasi secara efektif, empati, dan santun. Ketiga, beradaptasi di tempat bertugas di seluruh wilayah Republik

\footnotetext{
${ }^{86}$ Zakiah Daradjat, dkk., Metodik Khusus Pengajaran Agama Islam, (Jakarta: Bumi Aksara, 2004), h. 176

${ }^{87}$ Abuddin Nata, Ilmu Pendidikan Islam, (Jakarta: Kencana, 2010) Cet 1, h. 167

${ }^{88}$ Peraturan Menteri Pendidikan Nasional Republik Indonesia Nomor 16 Tahun 2007. http://hukum.unsrat.ac.id/men/mendiknas 16 2007.pdf (diakses tanggal 7 Juli 2017)

${ }^{89}$ Dalam Standar Nasional Pendidikan Pasal 28 ayat 3 butir b.
} 
ISTIGHNA, Vol. 1, No 1, Januari 2018 P-ISSN 1979-2824

Homepage: http://e-journal.stit-islamic-village.ac.id/index.php/istighna

Maemunah

Eksistensi Pendidikan Agama Islam Dalam Membangun Toleransi Beragama

Indonesia. Keempat, berkomunikasi dengan komunitas profesi sendiri dan profesi lain secara lisan dan tulisan atau dalam bentuk lain. ${ }^{90}$

d. Kompetensi Profesional, merupakan penguasaan materi pembelajaran secara luas, sehingga guru dapat membimbing siswa memenuhi standar kompetensi yang ditetapkan. Kompotensi ini meliputi; menguasai secara luas dan mendalam substansi dan metodologi dasar keilmuan, menguasai materi ajar dalam kurikulum, mampu mengembangkan kurikulum dan aktivitas belajar mengajar, menguasai dasar-dasar materi kegiatan, serta mampu menilai dan memperbaiki pembelajaran melalui penelitian dan tindakan kelas. $^{91}$

Dari keempat kompetensi guru tersebut, diharapakan setiap guru mampu menguasainya, sehingga dalam pembelajaran seorang guru bisa bersikap demokratis. Dengan sikap demokrais dalam tingkah lakunya, baik sikap maupun perkataan, tidak diskriminatif terhadap siswa yang menganut agama yang berbeda dengannya, serta memiliki kepedulian yang tinggi terhadap kejadian-kejadian tertentu yang ada hubungannya dengan agama. ${ }^{92}$

3. Lingkungan sekolah

Dalam menanamkan nilai toleransi di lingkungan sekolah, harusnya sekolah menyediakan ruang bagi tumbuhnya kerberagamaan dan kemajemukan untuk memberikan pemahaman tentang perbedaan dalam kerukunan beragama. Lingkungan sekolah yang multikultural dan pluralis harus memiliki kebijakan-kebijakan yang mendukung kearah tersebut, diantaranya dengan menerapkan undang-undang lokal yang diterapkan di sekolah. Salah satu point terpenting dari undang-undang tersebut adalah adanya larangan terhadap segala bentuk diskriminasi agama di sekolah.

Dengan demikian, melalui tiga faktor yang mempengaruhi terbentuknya toleransi beragama tersebut diharapkan menjadi alat sebuah pemersatu bangsa

${ }^{90}$ Peraturan Menteri Pendidikan Nasional Republik Indonesia Nomor 16 Tahun 2007. http://hukum.unsrat.ac.id/men/mendiknas_16 2007.pdf (diakses tanggal 7 Juli 2017).

${ }^{91}$ Syaiful Sagala, Kemampuan Profesional Guru dan Tenaga Kependidikan, (Bandung: Alfabeta, 2009). h. 39-40

${ }^{92}$ M. Ainul Yaqin, Pendidikan Multikultural: Cross-Understanding Untuk Demokrasi dan Keadilan, (Yogyakarta: Pilar Media, 2005), h. 62 
ISTIGHNA, Vol. 1, No 1, Januari 2018 P-ISSN 1979-2824

Homepage: http://e-journal.stit-islamic-village.ac.id/index.php/istighna

Maemunah Eksistensi Pendidikan Agama Islam Dalam Membangun Toleransi Beragama

dalam terbentuknya kedamaian dan kerukunan umat beragama, serta saling menghargai dan menghormati keberagamaan baik di lingkungan sekolah maupun di lingkungan masyarakat. Toleransi beragama dan penerapan di dunia pendidikan, tentu menjadi bagian terpenting dalam menciptakan kedamaian dan kerukunan antarumat beragama. Sehingga menjadi sebuah budaya yang baik yang bisa terus menerus yng akan menjadi alat pemersatu bangsa. Oleh karena itu, hal ini menjadi hal yang sangat penting untuk tetap diperhatikan dan diterapkan terutama di dunia pendidikan yang akan diaplikasikan di masyarakat.

\section{F. Penutup}

Dari pemaparan di atas mengenai eksistensi pendidikan Islam dalam membangun toleransi beragama, dapat tercipta dengan membentuk sikap toleransi beragama dengan cara sebagai berikut:

1. Melakukan kegiatan-kegiatan sosial yang melibatkan para pemeluk agama yang berbeda.

2. Mengubah orientasi pendidikan agama yang menekankan aspek fiqhiyah menjadi pendidikan agama yang berorientasi pada pengembangan aspek universal rabbaniyah.

3. Meningkatkan pembinaan individu yang mengarah pada terbentuknya pribadi yang memiliki budi pekerti yang luhur dan akhlaqul karimah.

Serta kontribusi Pendidikan Agama Islam dalam menciptakan suasana toleran di dunia pendidikan dipengaruhi oleh kurikulum, kompetensi guru dan lingkungan sekolah.

\section{DAFTAR PUSTAKA}

Agil Husin Al-Munawwar, Said, Fikih Hubungan Antar Agama, (Jakarta: Ciputat Press, 2005)

Al-Ghazali, Muhammad, al-Islam al-Muftara 'Alayhi, (Kairo: Nahdatu Misr, 2008)

Al-Muhit, Oxford Study Dictionary English - Arabic, (Beirut: Academia, 2008)

Al-Qardhawi, Yusuf, Ghairul-Muslimin fiiil Mujtama' Al Islami, (Qahirah: Maktabah Al-Wahbah, 2002) 
ISTIGHNA, Vol. 1, No 1, Januari 2018 P-ISSN 1979-2824

Homepage: http://e-journal.stit-islamic-village.ac.id/index.php/istighna

Maemunah Eksistensi Pendidikan Agama Islam Dalam Membangun Toleransi Beragama

Azra, Azyumardi, Menuju Masyarakat Madani,: Gagasan, Fakta, dan Tantangan, (Bandung: Remaja Rosda Karya, 1990)

Bank, James A, Handbook of Research on Muticultural Education http://www.educationworld.com

Baghi, Felix, Pluralisme, Demokrasi, dan Toleransi, (Maumere: Ladero, 2012)

Baidhawy, Religion education Multicultural Perspective, (Surakarta: Pusat Studi Budaya dan Perubahan Sosial Universitas Muhammadiyah Surakarta, 2005)

Daradjat, Zakiah, dkk., Metodik Khusus Pengajaran Agama Islam, (Jakarta: Bumi Aksara, 2004), ${ }^{1}$ Zakiah Daradjat, dkk., Metodik Khusus Pengajaran Agama Islam, (Jakarta: Bumi Aksara, 2004)

Dewey, John, Democracy and Education, (The Free Press)

Direktorat Pendidikan Agama Islam pada Sekolah Departemen Agama RI, Laporan Workshop Penelitian Multikultural Pertama, (Jakarta: Direktorat Pendidikan Agama Islam pada Sekolah Departemen Agama RI, 2008)

Fanani, A. Fuad, Islam Mazhab Kristis: Menggagas Keragaman Liberti, (Jakarta: Kompas Gramedia, 2004)

Kahmad, Dadang, Sosiologi Agama, (Bandung: Rosda Karya, 2000)

Kantor Wilayah Kementrian Agama Sosialisasikan PP No.55 Tahun 2007 Tentang Pendidikan Agma adan Keagamaan, Direktorat Jendral

Pendidikan Islam Kementrian Agma RI, http://pendis.kemenag.go.id

Kasiram, Moh., dkk, Sejarah Pendidikan Islam, cet II, (Jakarta: Dirjen Pembinaan Kelembagaan Agama Islam, 1986)

Kementrian Agama RI Badan Litbang dan Diklat Puslitbang, Toleransi Beragama

di Daerah Rawan Konflik, (Jakarta: Puslitbang Kehidupan Keagamaan, 2016)

Ma'arif, Syamsul, Pendidikan Pluralisme di Indonesia, (Jogjakarta: Logung Pustaka, 2005)

Misrawi, Zuhairi, Al-Qur'an Kitab Toleransi: Tafsir Tematik Islam Rahmatan Lil'alamin, (Jakarta: Grasindo Pustaka Oasis, 2010)

Muhammad al-Toumy Al-Syaibani, Omar, Falsafah Pendidikan Islam, penerjemah Hasan Langgulung, (Jakarta: Bulan Bintang, 1979) 
ISTIGHNA, Vol. 1, No 1, Januari 2018 P-ISSN 1979-2824

Homepage: http://e-journal.stit-islamic-village.ac.id/index.php/istighna

Maemunah Eksistensi Pendidikan Agama Islam Dalam Membangun Toleransi Beragama

Nata, Abuddin, Ilmu Pendidikan Islam, (Jakarta: Kencana, 2010)

Nurmaliah, Yayah, Pendidikan Agama Islam Pluralis, disertasi SPs UIN Syarif Hidayatullah Jakarta, 2009

Peraturan Menteri Pendidikan Nasional Republik Indonesia Nomor 16 Tahun 2007

http://hukum.unsrat.ac.id/men/mendiknas_16_2007.pdf

Peres, Zagorin, How the Idea of Religious Toleration Came to the West, (Princeton University Press, 2003)

Qutub, Sayyid, Tafsir Fi Zilal al-Qur'an, jilid 4, (Kairo: Dar al-Syuruq, 1982)

Raji Al-Faruqi, Ismail, Tauhid, (Bandung: Pustaka, 2008)

Russel, Jenice R, Religious Tolerance, Education and The Curriculum, The Netherlands (2011), 12. http://www.sensepublishers.com

Sagala, Syaiful, Kemampuan Profesional Guru dan Tenaga Kependidikan, (Bandung: Alfabeta, 2009)

Singh, Gurbachan, Equality and Education, (Derby: Albrighto Publications, 1993) Stiftung, Bertelsmann, "A Modern Concept of Tolerance Basis for Democratic Interaction in Pluralistic Societies," http://www.bertelsmannstiftung.pdf (diakses pada tanggal 17 Juli 2017).

Tafsir, Ahmad, Ilmu Pendidikan dalam Perspektif Islam, Cet.IX, (Bandung; Remaja Rosdakarya, 2010)

The new International Webster Chomprehensive Dictionary of The English Language, (Chicago: Trieden Press International, 2006)

Tilaar, H.A.R, Multikulturalisme: Tantangan-Tantangan Global Masa Depan dalam Transformasi Pendidikan Nasional, (Jakarta: Grasindo, 2004)

UNESCO, "Learning to Live Together In Peaceand Harmony: Values Education for Peace, Human Rights, Democracy and Sustainable Development fortheAsia-PasificRegion," http://unesdoc.unesco.org/pdf

Yaqin, M. Ainul, Pendidikan Multikultural: Cross-Understanding Untuk Demokrasi dan Keadilan, (Yogyakarta: Pilar Media, 2005) 